\title{
Antara Teori Formula Albert B Lord dan Musikologi
}

\author{
Nugrahanstya Cahya Widyanta \\ Program Studi Seni Musik, Fakultas Bahasa dan Seni \\ Universitas Kristen Satya Wacana \\ email: nugrahanstya cahya@yahoo.com
}

\begin{abstract}
ABSTRAK
Kajian sastra lisan dan musikologi memiliki keterkaitan yang belum banyak diungkapkan. Tulisan ini ingin menunjukkan bahwa musik merupakan bingkai kelisanan untuk menggiring sebuah keteraturan dalam pengkalimatan karya sastra lisan Yugoslavia. Hal tersebut diteliti dengan menggunakan metode kualitatif. Analisis data dilakukan melalui tiga tahap, yaitu reduksi data, penyajian data, dan mengambil kesimpulan kemudian melakukan verifikasi. Data yang diperoleh bersumber dari buku The Singer of Tales tulisan Albert B Lord yang mencakup penjelasan mengenai teori formula dalam sastra lisan Yugoslavia. Data tersebut dianalisis menggunakan teori bentuk dan struktur musikal Leon Stein. Komposisi dalam karya kelisanan tersebut dikaji melalui teori formula Lord. Dalam hal ini, pelantun mengingat perulangan dan menciptakan melalui analogi dengan perulangan kata, frasa, klausa, dan larik yang telah ada. Terdapat proses akumulasi, kombinasi, dan pemodelan kembali terhadap formula yang telah ada. Dengan demikian setiap pelantun memiliki gayanya masing-masing dalam penceritaan karya sastra lisan tersebut, namun setiap pelantun selalu memiliki jumlah suku kata yang sama dalam setiap pengkalimatan. Hal ini dapat terjadi dikarenakan rasa musikal yang dipakai. Para pelantun tidak pernah menghitung jumlah suku kata yang ada namun keteraturan tersebut dapat terjadi karena adanya rasa musikal.
\end{abstract}

Kata kunci: teori formula, Albert B Lord, sastra lisan, musikologi.

\section{ABSTRACT}

Study of oral literature and a discipline named musicology have a linkage that has never been very often expressed yet. This paper is to reveal that music is an oral frame to bring a regularity in making sentences of oral literature works in Yugoslavia. Such a thing is researched using a qualitative method. Data analysis is done through three steps, they are data reduction, data display, and conclusion and verification. The data is taken from a book entitled The Singer by Albert B Lord containing his theoretical formula concerning the oral literature in Yugoslavia. It is analysed by using a theory of musical form and structure by Leon Stein. Compositions in the oral literature is seen using Lord's theory of formula. In this case, a singer remembers the repetition and creates it by analogy by the way of repeating the existing words, phrases, clauses, and arrays. There is a process of re-accumulating, re-combinating, and re-modelling the existing formula. So, the singer has his or her own style in expressing 
the works of the oral literature, but he or she always has the same number of syllables in every sentence. This can happen due to the musical taste used. The singer never count the number of syllables that exists but such regularity can occur due to the musical taste.

Keywords: formula theory, Albert B Lord, musicology, oral literature.

\section{PENDAHULUAN}

Teori formula Albert B Lord dalam studi ini digunakan untuk mengkaji puisi lisan Yugoslavia untuk menjelaskan atau membuktikan kelisanan iliad dan Odyssey karya Homeros. Menurut Lord dalam bukunya The Singer of Tales (1971: 30-43), formula adalah kelompok kata yang secara teratur dimanfaatkan dalam kondisi matra yang sama untuk mengungkapkan suatu ide yang esensial atau pokok. Formula itu muncul berkali-kali dalam cerita, yang mungkin berupa kata, frasa, klausa, atau larik. Untuk menghasilkan perulangan itu, ada dua cara yang ditempuh oleh pencerita/pelantun, yaitu mengingat perulangan dan menciptakan melalui analogi dengan perulangan kata, frasa, klausa, dan larik yang telah ada. Adapun formulaik merupakan larik atau paro larik yang disusun atas dasar pola formula.

Dalam teori formula Lord, konsep kelisanan tidak hanya dimaknai sebagai presentasi lisan, tetapi juga dimaknai sebagai komposisi selama terjadinya penampilan secara lisan. Selanjutnya, Lord menjelaskan bahwa upaya untuk mempelajari, menyusun, dan menampilkan suatu karya secara lisan merupakan bentuk rangkaian kelisanan yang dimaknai sebagai kelisanan dalam arti teknis/harfiah.

Hal yang sama terjadi juga dalam bentuk improvisasi. Dalam teori formula, prinsip kelisanan berorientasi pada proses pembelajaran tertentu, yakni adanya unsur pembelajaran lisan, komposisi lisan dan transmisi lisan yang muncul hampir bersamaan sehingga tampak sebagai sisi-sisi yang berbeda dari proses yang sama.

Formula tersebut berulang-ulang muncul dalam cerita yang meliputi frasa, klausa, atau larik. Untuk menghasilkan frasa itu, ada dua cara yang ditempuh oleh pencerita yaitu dengan mengingat frasa itu dan dengan menciptakan melalui analogi frasa-frasa lain yang pernah ada. Hal ini sesuai dengan pendapat Lord yang menyatakan ada tiga tahap dalam proses komposisi atau cara pemerolehan lagu secara lisan, yaitu peletakan fondasi dengan cara mendengarkan atau melakukan penyerapan, penerapan atau aplikasi, dan pelantunan di hadapan pendengar. 
Menurutnya, ketiga proses komposisi tersebut senantiasa diikuti atau dilanjutkan dengan proses mengakumulasi, mengombinasikan dan memodelkan kembali formula yang telah ada.

Lord juga menjelaskan bahwa penyair lisan dalam melantunkan puisi lisan (lagu) tidak akan sama persis, meskipun bersumber dari puisi lisan yang sama. Hal ini disebabkan penyair lisan hanya menghafalkan formulanya saja sehingga ketika melantunkan puisi lisan (dalam performance) terdapat perubahan atau penambahan. Formula digunakan untuk menemukan frasa atau kata yang diulang-ulang dalam sastra lisan. Fungsi formula adalah untuk mengingat kata-kata atau tema yang ada dalam sastra lisan.

Dengan pola formula sebagai dasar, pelantun dapat menyusun larik-larik dengan cepat pada posisi tertentu. Dalam penyusunan baris dengan pola formula itu terjadi proses penggantian, kombinasi, pembentukan model, dan penambahan katakata atau ungkapan baru pada pola formula sesuai dengan kebutuhan penceritaan atau penggubahan. Pelantun dapat membangun larik terus menerus, sesuai dengan keinginan dan kreatifitasnya.

Formula dan ekspresi formulaik bertujuan untuk menceritakan kisah-kisah dalam nyanyian dan sajak. Formula merupakan alat untuk menuangkan tema atau ide-ide yang disampaikan kepada audience. Pelantun berpikir dan mempertimbangkan berdasarkan pola formula untuk menyajikan cerita. Penguasaan formula merupakan syarat utama dalam menggubah cerita secara mudah dan lancar. Dengan paradigma tensis dan penafsiran mengubah bentuk kata untuk membedakan kasus, jenis, jumlah, dan aspek, bahasa yang dimanfaatkan dalam puisi lisan cenderung bersifat mekanis dan paralelistis. Hal ini terbukti dominannya penggunaan formula dalam puisi lisan.

Formula merupakan frase-frase, klause-klause, dan kalimat-kalimat yang khas. Formula yang stabil akan menjadikan ide-ide puisi lisan yang umum dengan mengemukakan kata kunci dari nama-nama aktor, tindakan, waktu, dan tempat yang utama. Pola-pola dan sistem-sistem dalam puisi lisan banyak menggunakan "tata bahasa khusus" atau "tata bahasa puisi" (grammar of poetry), yakni berupa "tata bahasa super impos" atau "tata bahasa yang berlapis" (grammar of superimposed). Selain itu, tata bahasa puitik dari puisi lisan juga merupakan tata bahasa parataksis (grammar of parataxis) yakni konstruksi kalimat, klausa, atau frase koordinatif yang 
tidak menggunakan kata penghubung. "Tata bahasa" tersebut sering memanfaatkan frase-frase yang membentuk formula.

Sebagaimana telah disinggung bahwa prinsip kelisanan berorientasi pada proses pembelajaran sehingga tidak hanya terbatas pada presentasi lisan. Dengan prinsip tersebut, menurut Lord, teks-teks yang dianggap sakral harus ditransmisikan kata demi kata (teks pasti) tidak dapat dikatakan memiliki prinsip kelisanan, kecuali dalam pengertian teknis atau harfiah.

\section{METODE PENELITIAN}

Penelitian mengenai keterkaitan antara teori formula Lord dengan dan disiplin ilmu berupa musikologi menggunakan metode deskriptif kualitatif. Data yang diperoleh bersumber dari buku The Singer of Tales tulisan Albert B Lord yang mencakup penjelasan mengenai teori formula dalam sastra lisan Yugoslavia. Data tersebut dianalisis menggunakan teori bentuk dan struktur musikal Leon Stein. Teori bentuk dan struktur musikal digunakan untuk mengetahui sejauh mana teori formula dalam sastra lisan berkaitan dengan musikologi sebagai disiplin ilmu.

Winarno Surakhmad (dalam Soedjono dan Abdurrahman, 2005: 22) mengatakan bahwa pelaksanaan metode-metode deskriptif tidak terbatas hanya sampai pada pengumpulan dan penyusunan data, tetapi meliputi analisis dan interpretasi tentang arti data itu. Oleh sebab itu, metode analisis digunakan untuk dapat melakukan pemeriksaan secara teliti mengenai keterkaitan teori formula dalam sastra lisan dengan musikologi. Analisis data dilakukan melalui tiga tahap, yaitu: (1) reduksi data, (2) display/penyajian data, dan (3) mengambil kesimpulan lalu verifikasi.

\section{HASIL DAN PEMBAHASAN}

\section{Formula sebagai Pijakan Membangun Komposisi}

Lagu narasi Yugoslavia memiliki teknik bernyanyi yang berasal dari orang tua/gurunya. Si pelantun narasi adalah pewaris teknik tersebut dengan melakukan rekapitulasi pengalaman dari generasi sebelumnya. Dari mendengar si pelantun narasi menyerap ritme-ritme epik dari lagu tersebut. sehingga dapat dikatakan bahwa si pelantun belajar secara empiris mengenai panjang kalimat, irama cadens, dan alur melodi pada narasi. Penyanyi tradisi Yugoslavia memiliki rasa sepuluh suku 
kata diikuti dengan jeda sintaksis, meskipun ia tidak pernah menghitung sepuluh suku kata tersebut, dan jika ditanya ia tidak bisa menyebutkan berapa banyak suku kata yang ada antara jeda tersebut.

Dengan cara yang sama si pelantun menyerap alur melodi ke dalam pengalamannya sendiri dengan penambahan variasi aksen pada suku kata saat perform/tampil. Variasi yang halus disebabkan oleh permainan aksen tonik, panjang vokal dan garis melodi. Hal ini memberi batasan untuk si pelantun membuat alur melodi sendiri berdasarkan dunia imajinatifnya sendiri.

Berbicara mengenai tradisi lisan, maka tidak akan terlepas dari konteks pementasan atau performansinya. Sehubungan dengan itu, selain berbicara tentang formula sebagai ciri utama kelisanan, Lord juga menekankan aspek- aspek kelisanan puisi Yugoslavia berupa komposisi, performansi, dan transmisi. Menurut Lord, bagi penyair lisan, pembuatan komposisi dilakukan saat ia melakukan performansi (pertujukan) sehinga komposisi dan performansi merupakan dua hal yang dilakukan pada saat bersaman. Lord mengatakan bahwa tidak ada komposisi, tetapi ada di dalam performansi. la menjelaskan ada tiga tahap dalam proses komposisi, yaitu peletakan pondasi dengan cara mendengarkan atau melakukan penyerapan,penerapan atau aplikasi, dan pelantunan di hadapan pendengar.

Selanjutnya Lord mengatakan bahwa proses komposisi tersebut dilanjutkan dengan proses mengakumulasi, mengkombinasi dan memodelkan kembali formula yang telah ada. Para penyair lisan dalam melantunkan puisi lisan (lagu) tidak akan sama persis, meskipun bersumber dari puisi lisan yang sama. Hal ini disebabkan karena penyair lisan hanya menghafal formulanya saja, sehinga dalam performansi terdapat perubahan, penambahan atau kesalahan. Dengan demikian, hal semacam ini dapat memberi penegasan tentang proses yang terjadi dalam proses transmisi dalam tradisi lisan.

Walaupun ada persaman dengan lantunan karya Homer, khususnya tentang paralelisme dan repetisi, hasil penelitan Lord menunjukan pergeseran yang menarik untuk digarisbawahi. Lantunan karya Homer sangat panjang, sedangkan pada nyanyian rakyat masyarakat Yugoslavia tidak ditentukan panjang pendeknya baris, karena berkaitan dengan kemampuan pelantun dalammengekspresikan ide dan mengelaborasi tema. Oleh karena itu, walaupun mengekspresikan ide yang sama, seorang pelantun mampu melantunkan baris- baris yang sangat panjang, tetapi 
pelantun yang lain hanya mampu melantunkanlantunan yang relatif pendek. Tokoh lantunan Homer adalah para dewa/dewi ataumanusia setengah dewa/dewi, sedangkan tokoh lantunan dalam nyanyianmasyarakat Yugoslavia berkisar pada kehidupan kerajan atau kesultanan. Istilah epik pun tidak hanya merujuk pada masalah kepahlawanan seseorang yang dilantukan dalam ribuan baris seperti gejala yang ditemukan pada lantunan Homer.

Bagi temuan Lord, puisi epik lebih bersifat narative oral poetry. Tema lantunan pun lebih bervariasi, hal ini dipengaruhi oleh pengetahuan dan perasan seorang penyanyi ketika ia melantunkan nyanyianya. Pada nyanyian masyarakat Yugoslavia, repetisi lebih merupakan konvensi, yaitu adanya pengulangan kerangka ketika melantunkan puisi lisan (schemata compositon).

Terkait dengan pola ritmis, pelantun harus belajar untuk mengendalikan batas kata, atau lebih tepatnya disebut panjang kelompok aksentual. Kebutuhan ini sangat penting untuk penyanyi karena rasa untuk istirahat jeda di pertengahan garis harus sangat nyata. Sebuah kelompok aksentual tidak bisa, dan dalam praktek sangat jarang tidak, menjembatani suku kata keempat dan kelima, meskipun tidak ada pola melodi maupun ritmis yang menunjukkan ini. Ketika mendengarkan lagu yang mendengar tidak terdengar seperti ada jeda dipertengahan.

Lord menyatakan bahwa penyair-penyair itu tidak menghafalkan puisinya lewat naskah atau tulisan. Setiap penyair tradisional membawakan ceritanya dengan menciptakan kembali secara spontan dan memakai sejumlah unsur bahasa (kata, kata majemuk, frasa) yang tersedia baginya (stock-in-trade) yang siap pakai (Lord, 1971:34). Unsur-unsur yang dipakai memperlihatkan bentuk yang identik atau variasi sesuai dengan tuntutan tata bahasa, matra, dan irama puisi yang dipakai.

Namun dalam setiap pertunjukan tidak ada bentuk penciptaan yang spontan seratus persen, tetapi pencerita memakai sejumlah formula yang merupakan stereotipe yang siap pakai dengan kemungkinan variasi menurut tata bahasa. Persediaan formula disebut stock-in-trade si penyair, pencerita, atau tukang pidato. Setiap kali seorang tukang cerita atau pembawa puisi naratif lisan berpentas, dia mengucapkan kembali secara baru dan spontan gubahannya. Hal itu terbukti bahwa jarang terdapat penghafalan dan tidak ada dua pementasan yang sama, bahkan seorang pencerita yang sama, yang identik penampilannya. Pencerita mempunyai kebebasan memilih dan memasangkan formula itu pada saat pertunjukan. Teknik 
formula dikembangkan untuk membuktikan bahwa dirinya sebagai seorang ahli seniman.

Beberapa poin menarik temuan Lord adalah: (1) pelantunan puisi lisan dalam masyarakat Yugoslavia bersifat spontan, karena dilantunkan langsung di tempat pelantunan tanpa catatan; (2) pelantunan hanya menyiapkan plot dan tema; (3) pelantunan didominasi oleh repetisi dan paralelisme; (4) lantunan diperkaya dengan stock epithet, yaitu frase siap pakai yang telah disediakan adat; (5) lantunan mengandung formula, yaitu kata atau frase yang digunakan untuk mengisi tempat kosong pada bait-bait selanjutnya yang mempunyai kesejajaran semantik tertentu; (6) ditemukan kesatuan antara singer-composer-performer dalam pelantunan; dan (7) tidak ada istilah original dan varian untuk lantunan karena setiap lantunan adalah asli atau selalu diproduksi kembali.

\section{Elemen Dasar Musikal sebagai Bingkai Formula}

Dalam musikologi khususnya dalam ilmu analisis bentuk musik terdapat beberapa unsur musikal yang membentuk sebuah kalimat lagu antara lain adalah figur, motif, semi frase, frase, period (Stein, 1979:4). Pada dasarnya dari beberapa unsur tersebut terdapat dua garis besar yang membentuk suatu tema kalimat lagu yakni motif dan period. Menurut hemat penulis, bila dikaitkan dengan formula dan formulaik pada sastra maka analoginya adalah motif sama artinya dengan formula dan period sama artinya dengan formulaik. Motif merupakan gagasan dasar dari pola yang diulang-ulang sedangkan period merupakan kalimat musikal yang terbentuk berdasarkan rangkaian dari motif. Oleh karena itulah maka penulis memberanikan diri untuk menganalogikan motif sebagai formula dan period sebagai motif.

Terdapat pernyataan menarik bagi penulis yang dikemukakan oleh Lord yakni:

"Ekspresi formulaik dapat juga membantu terbentuknya wacana ritmis sehingga merupakan salah satu alat bantu untuk mengingat kembali dengan mudah, cepat, dan tepat serta menjadi ungkapan tetap yang dapat bertahan hidup secara lisan" (Lord, 1971:30).

Pernyataan tersebut menunjukkan bahwa sastra dan musik memiliki kaitan yang sangat erat. Musik bukan semata-mata hanya berbicara mengenai bunyi saja, karena musik memiliki empat elemen dasar musikal yakni pitch/nada, ritmis, 
dinamika, timbre/warna suara. Lord menyebutkan bahwa ekspresi formulaik dapat membantu terbentuknya wacana ritmis sehingga merupakan salah satu alat bantu untuk mengingat kembali dengan mudah, cepat, dan tepat serta menjadi ungkapan tetap yang dapat bertahan hidup secara lisan. Pernyataan tersebut tentu menjadi bukti kuat bahwa kelisanan iliad ini sangat berkaitan dengan 'ritmis' yang merupakan salah satu elemen dasar musikal. Hal ini diperkuatkan pula dengan cerita yang dikemukakan di dalam buku Lord bahwa si pelantun tidak paham berapa jumlah suku kata yang ia ucapkan bahkan ketika ditanya pun mereka menjawab tidak tahu, namun mereka selalu menampilkan penampilannya dengan jumah suku kata yang sama. Menurut hemat penulis, hal ini dapat terjadi lantaran pengaruh ritmis dalam pelantunannya.

Ritmis implementasinya adalah sukat atau tanda birama, tergambar dari cuplikan notasi yang ada dalam buku Lord bahwa ternyata pelantunan iliad pun setelah ditranskripsikan ke notasi balok memiliki tanda birama sehingga memiliki keteraturan pola ritmis yang pasti. Sukat merupakan sebuah bukti bahwa sistem ritmis dalam rangkaian komposisi iliad memiliki sebuah keteraturan. Musik tentunya sangat berkaitan erat dengan rasa, berdasarkan kemasan musik inilah ritmis akan mempengaruhi keteraturan jumlah suku kata. Bila suku kata tersebut tidak sesuai dengan ritmis yang telah ada maka akan terdengar ganjil secara rasa musikal. 
INTRODUCTION
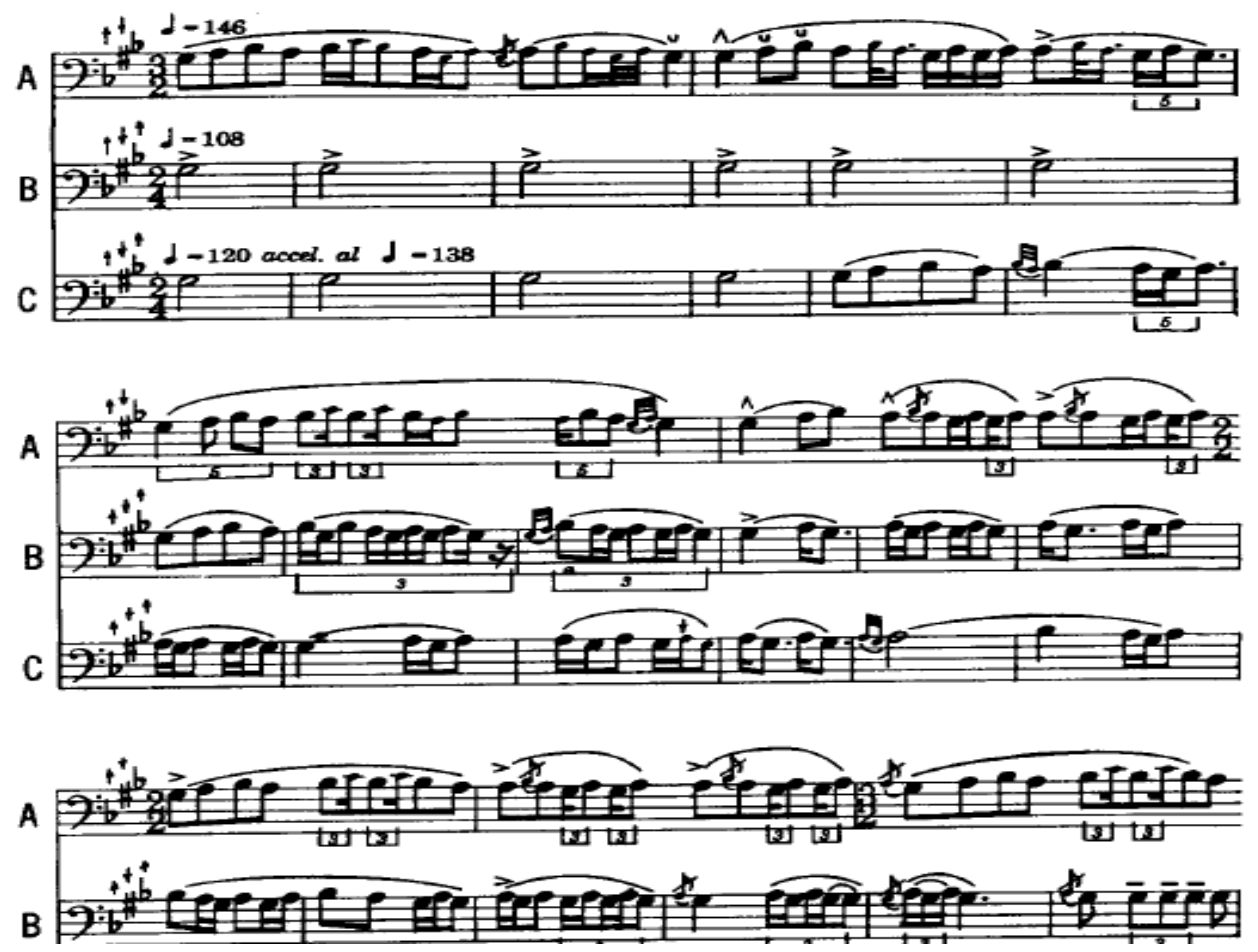

Gambar 1

Sukat sebagai Bukti Keteraturan Pola Ritmis

(Sumber: Lord, 1971: 40).

Setelah membahas mengenai ritmis, selanjutnya beralih pada pitch/nada. Pitch/nada implementasinya adalah melodi. Melodi merupakan rangkaian nada yang tersusun secara horisontal. Penulis ingin memaparkan bentuk musikal dari melodi kelisanan iliad.

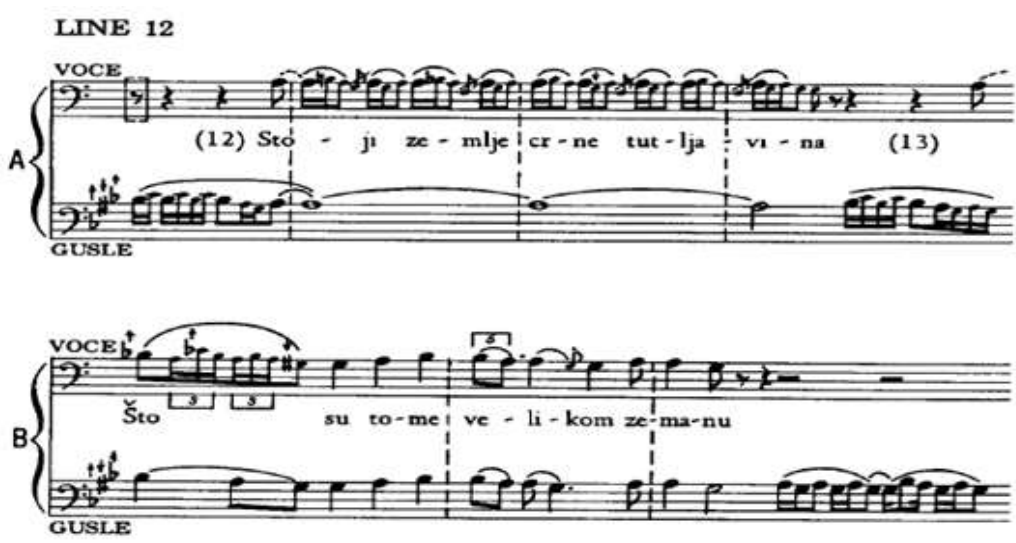

Gambar 2

Penggalan Satu Period Musikal

(Sumber: Lord, 1971: 41). 
Terdapat sebuah motif dalam penggalan kalimat yang tergambar melalui notasi pada Gambar 2. Motif tersebut kemudian dikembangkan menjadi sebuah frase dalam tiga birama. Frase pertama tersebut menjadi sebuah frase tanya yang kemudian diteruskan dengan frase jawab pada tiga birama berikutnya. Tergambar pada notasi Gambar 2, baris notasi dengan kurung kurawal A merupakan frase tanya sedangkan baris notasi dengan kurung kurawal B merupakan frase jawab dalam kalimat musikal.

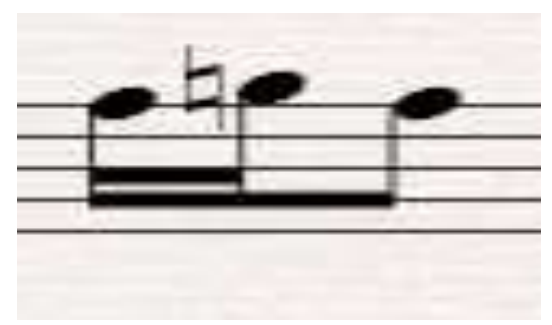

Gambar 3

Motif

(Sumber: Lord, 1971: 41).

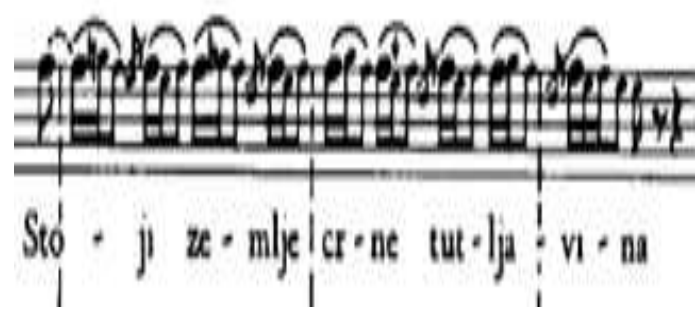

Gambar 4

Pengembangan Motif Menjadi Frase Tanya

(Sumber: Lord, 1971: 41).

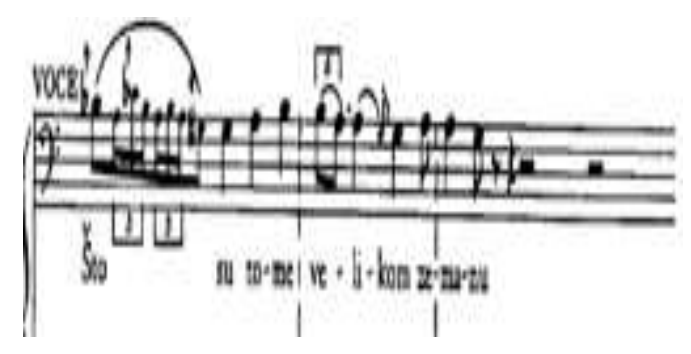




\section{Gambar 5}

Frase Jawab yang Merupakan Penyelesaian Period dari Frase Tanya

(Sumber: Lord, 1971: 41).

Pengembangan motif menjadi sebuah rangkaian melodi tersebut telah membentuk sebuah frase tanya yang kemudian diteruskan dengan frase jawab. Kedua frase tersebut membentuk sebuah period musikal atau kalimat musikal. Berdasarkan contoh tersebut dapat diketahui bahwa pengolahan kalimat bukan hanya didasari pada kelisanan saja namun juga mempertimbangkan aspek musikal.

Elemen dasar musikal selanjutnya adalah dinamika dan timbre. Dinamika tentu berkaitan dengan ekspresi pembawaan si pelantun. Jelas pada lantunan iliad terdapat ekspresi. Keras lirihnya pelantunan akan membangun suasana dan daya imajinatif para pendengar. Timbre berkaitan dengan warna suara. Tidak hanya pada iliad, permainan timbre juga sangat sering dijumpai pada pelantunan karya sastra lisan lainnya. Sebagai contoh ketika si pelantun menyuarakan karakter orang yang berwibawa ia akan membentuk timbre yang tebal. Lain tokoh karakter yang dibawakan lain pula timbrenya.

\section{SIMPULAN}

Dapat disimpulkan bahwa antara sastra dan musik memiliki keterkaitan yang tidak dapat dipisahkan. Dari hasil pengamatan penulis berdasarkan teori formula yang dikemukakan Lord, dalam pelantunan kelisanan mengandung keempat elemen dasar musikal yakni pitch/nada, ritmis, dinamika, dan timbre/warna suara. Pitch/nada dan ritmis merupakan elemen dasar musikal yang sangat tampak dalam sebuah lantunan kelisanan seperti yang telah dijelaskan sebelumnya.

Pitch/nada implementasinya adalah melodi. Melodi dalam kelisanan iliad rupanya memiliki kalimat musikal yang teratur di mana terdapat motif musikal yang kemudian dikembangkan menjadi sebuah frase tanya (anticedent) lalu diselesaikan dengan frase jawab (concequence) menjadi sebuah period atau kalimat musikal. Keteraturan kalimat musikal tersebut didukung pula oleh elemen musikal lainnya yakni ritmis. Ritmis implementasinya adalah sukat di mana satu birama memiliki 
jumlah nilai nada yang teratur. Sukat tersebut menggiring si pelantun untuk melantunkan jumlah suku kata yang sama pada setiap kalimatnya.

Dua elemen dasar musikal lainnya yakni dinamika dan timbre/warna suara juga terkandung dalam lantunan kelisanan. Dinamika berkaitan dengan ekspresi, keras lirihnya pembawaan cerita dari si pelantun, sedangkan timbre (warna suara) berkaitan dengan gaya si pelantun dalam membawakan tokoh karakter tertentu. Dalam kesempatan ini penulis memberanikan diri untuk menyatakan bahwa dalam sastra lisan teori Albert B Lord tidak akan dapat lepas dari musikologi karena keduanya saling berkaitan erat.

\section{DAFTAR PUSTAKA}

Duckworth, William; Edward Brown. 1987. Theoritical Foundation of Music. Belmont: California Wadsworth Publishing Company Inc.

Lord, Albert B. 1971. The Singer of Tales, New York: Harvard University Press.

Nattiez, Jean Jacques. 1990. Music and Discourse: Toward a Semiology of Music. (terj. Carolyn Abbate). New Jersey: Princeton University Press.

Soejono, H. Abdurrahman. 2005. Metode Penelitian suatu Pemikiran dan Penerapan, Jakarta: Rineka Cipta.

Stein, Leon. 1979. Structure \& Style The Study and Analysis of Musical Forms. USA: Summy Birchard, Inc.

Susanto, A. 1997. Komunikasi dalam Teori dan Praktek. Bandung: Bina Cipta. 